\section{Energy Dynamics of Developing Countries}

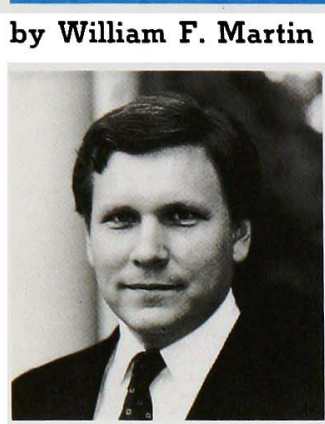

-昨年11月号と今年1月号 に揭載してきたW.F.マー チン氏による世界エネルギー 問題の論説も, 今回が最終回 である。まず中国，東アジ ア, インドなどの人口増加と 経済成長を背景とする世界工 ネルギー需要伸張を, 数值を 上げて説明している。そこで は石油, 石炭, 天然ガス, 原 子力への需要拡大がさまざま な問題を引き起こす。それに 対する先進国の役割，とくに 日米が果たすべきリーダシッ プついて述べている。最後 の段落, とくに最後の一文 は，まことに印象的である (マーチン氏の略歴は昨年 11 月号を参照のこと)。 大来 雄二 (東 芝)
Developing countries today account for more than one-quarter of world energy demand. By 2010, the International Energy Agency (IEA) projects their energy consumption to more than double, representing an unprecedented share (40 percent) of world energy demand. Supporting these trends are continued growth in population and economic development throughout developing countries -- specifically, urbanization, improved standards of living, industrialization, and increased mobility. The challenge for industrialized countries is to help meet the domestic energy demands of these growing populations while recognizing financial, institutional, and environmental challenges each country faces.

China is the third largest consumer of energy in the world, behind the United States and Russia. Given China's population growth and industrialization/modemization trends, its energy consumption is projected to increase by an average of four percent annually over the next decade. Coal will continue to be China's principal energy resource given its availability and cost-effectiveness. But the low quality of China's coal, emitting high levels of $\mathrm{CO}_{2}$, and the geographical mismatch between extraction and consumption pose serious problems for China. Despite large oil reserves, China became a net importer of oil in 1993. And its demand for oil is projected to grow by 2.8 percent per year, pushed by a rapid expansion of the transportation sector. Natural gas has been a major source of energy for China; however, given its high cost, natural gas will never complete with coal's dominance in the market. China has plans for an aggressive nuclear energy program, which raises concerns of safety and non-proliferation ; however, investment demands will deter full development of nuclear power.

According to the IEA, energy demand in East Asia will grow by 5.3 percent per year to 2000 and 4.6 percent thereafter, prompted by high rates of economic growth. Oil demand in East Asian countries increased 6 percent in 1993, the highest growing demand of any region in the world. These trends are expected to continue. This will increase the region's reliance on imported oil, especially from the Middle East. Coal is also an important energy resource for East Asia and is expected to maintain its strong role through the twenty-first century -- as East Asia becomes the fastest growing market for coal exports. Although East Asia has significant growth potential in natural gas production -currently accounting for three-quarters of world LNG trade -- it will never match the amount produced in Middle Eastern countries. South Korea and Taiwan have strong nuclear energy programs with ambitious plans for further development. Safety and non-proliferation concerns have been raised in the region as additional nuclear power programs are expected to be started in Indonesia and the Philippines.

High rates of economic growth are burdening energy infrastructures in South Asia, particularly India. The World Bank estimates that energy demand in India will increase 5.6 percent, making the demand level in 2005 2.5 times as large as that of 1990 . By 2020 , India's population is projected to surpass China's, although India's per capita will remain lower than China. India's oil, gas and coal reserves are likely to meet its energy demand in the near future. Privatization and deregulation of these markets is encouraging foreign investment at a record pace and maintaining domestic development -- although expanded use of low quality coal carries environmental implications. There are possibilities of expanding natural gas imports from Central Asia. But, political difficulties over trans-regional pipeline routes may deter construction. India would like to adopt a strong nuclear energy program as electricity needs deplete avarlable resources, but financial constraints and non-proliferation concerns will slow implementation.

Developing countries face immediate challenges of meeting domestic energy demands, underpinned by polulation growth and economic expansion. Developing countries' estimated trends for energy consumption raise dangerous implications of global concern. Developing countries will become over -dependent on imported oil from the Middle East, threatening global energy security. Because of its availability and cost -effectiveness, coal will remain a major energy resource for developing countries, contributing to the threat of global warming and regional acid rain. Moreover, with developing countries' plans for adopting nuclear energy programs, regional proliferation concerns will escalate.

To curb these projected trends, industrialized countries should encourage economically attractive and environmentally safe sources of energy, disseminate technical expertise, and introduce energy efficient technologies. As the two most advanced countries in the world, Japan and the United States should lead this effort, as well as the continued pursuit of liberalized trade -- promoting competitive goods and services. Given the market trends of heavy and energy intensive industry moving to developing countries, the key to continued global industrialization and welfare lies in the assurance that these developing regions will receive an adequate, reliable and environmentally-sensitive supply of energy. 